\title{
Selective Formation of 1,3,4-Trisubstituted and 3,4-Disubstituted Trans- $\beta$ -lactams from Zinc Enolates and Imines
}

Johann T.B.H. Jastrzebski, Fred H. van der Steen and Gerard van Koten*.

University of Utrecht, Laboratory of Organic Chemistry, Dept. of Metal-Mediated Synthesis Padualaan 8, 3584 CH Utrecht, The Netherlands.

(Received July 22nd, 1987)

\begin{abstract}
A new route for the high yield synthesis (better then $90 \%$ ) of exclusively trans- $\beta$-lactams (azetidin-2-ones) is reported which involves the $1: 1$ reaction of an $\alpha$-aminoacid ester zinc enolate with an appropriate imine. The reaction can be carried out as a 'one-pot' synthesis as has been demonstrated for the synthesis of trans-3-diethylamino-4-phenyl azetidin-2-one (93\% yield ). The novel zinc enolates have most likely a Z-geometry as a result of intramolecular chelate coordination. Evidence has been obtained that in the first step these zinc enolates react with the imine in a highly diastereoselective manner providing the threo aldolate which in a subsequent step undergoes ring closure to the azetidin-2-one.
\end{abstract}

$\beta$-Lactams are the principal building blocks of naturally occurring and synthetic penicillins ${ }^{1}$ and therefore much effort has been spent in the development of new and efficient procedures for their preparation. ${ }^{2}$ Compared to the large number of studies concerning the aldol condensation, ${ }^{3}$ parallel investigations on the condensation of metal enolates with imines, which in principle would lead to $\beta$-lactams or $\beta$-lactam precursors, have been far less numerous. The stereochemical aspects of the latter reactions have been covered in a review of the Reformatsky reaction. ${ }^{4}$ Procedures have been described in which $\beta$-lactams are obtained from the reaction of lithium ester enolates with either simple imines 5,6 or secondary $\mathrm{N}$-(cyanomethyl)amines. ${ }^{7}$ From these reactions the $\beta$-lactams are isolated either as cis/trans mixtures or solely as the cis stereoisomer. The synthesis of trans-3-benzoylamine substituted $\beta$-lactams, starting from the dianion of $\mathrm{N}$-benzoyl substituted amino acid esters and imines, have been reported. However, this procedure is

limited to the synthesis of 1,4-diaryl substituted $\beta$-lactams. ${ }^{5}$ We recently found that 1,3,4-trisubstituted trans- $\beta$-lactams are the exclusive products from the reaction of $\alpha$-iminoesters with diethylzinc. ${ }^{8 \mathrm{a}}$ In these reactions zinc enolates were proposed as important intermediates. We now report the use of this knowledge for an easy and selective synthesis of 1,3,4-trisubstituted and 3,4-disubstituted trans- $\beta$-lactams that is based on the condensation reaction of an preformed $\alpha$-aminoacid ester zinc enolate with an appropriate imine.

Reaction of a benzene solution of $\mathbf{3 a}$, the ethylzinc enolate of $\mathrm{Et}_{2} \mathrm{NCH}_{2} \mathrm{COOEt}$ ( prepared from the reaction of the lithium ester enolate 2 (vide infra) with $\mathrm{Et} \mathrm{ZnCl}$ ), with one equivalent of $\mathrm{N}$-methylbenzaldimine $\left(80^{\circ} \mathrm{C}, 1 / 2 \mathrm{~h}\right.$.) affords in quantitative yield the $\beta$-lactam trans-1-(N,N-diethylamino)-4-phenylazetidin-2-one, $4 \mathrm{a}$, and ethylzinc ethoxide as shown in Scheme 1. Under the same conditions $3 \mathbf{b}$, the chlorozinc enolate of $\mathrm{Et}_{2} \mathrm{NCH}_{2} \mathrm{COOEt}$ (prepared from 2 and $\mathrm{ZnCl}_{2}$ ), reacts with $\mathrm{N}$-methylbenzaldimine to afford the same

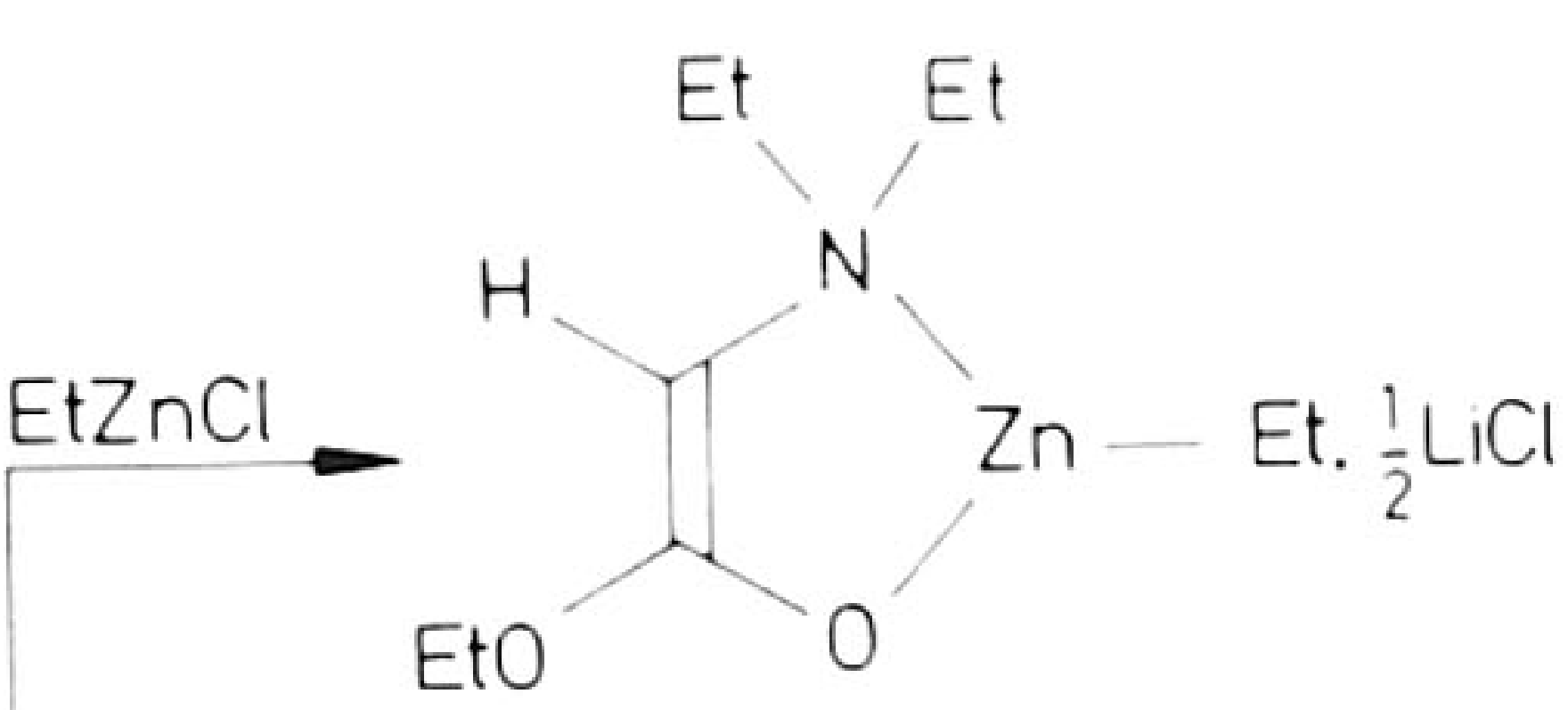

$3 a$

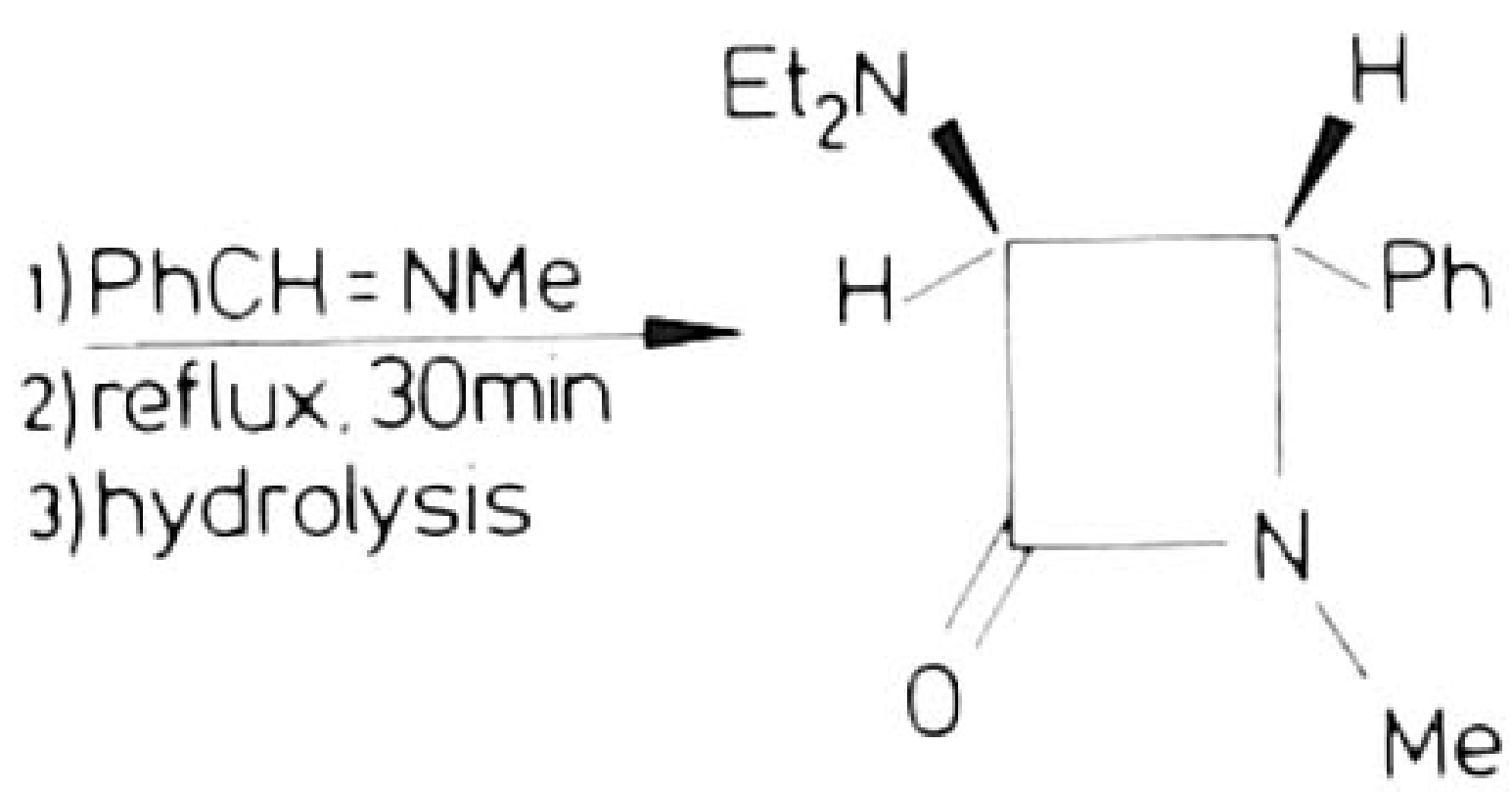

$4 a$

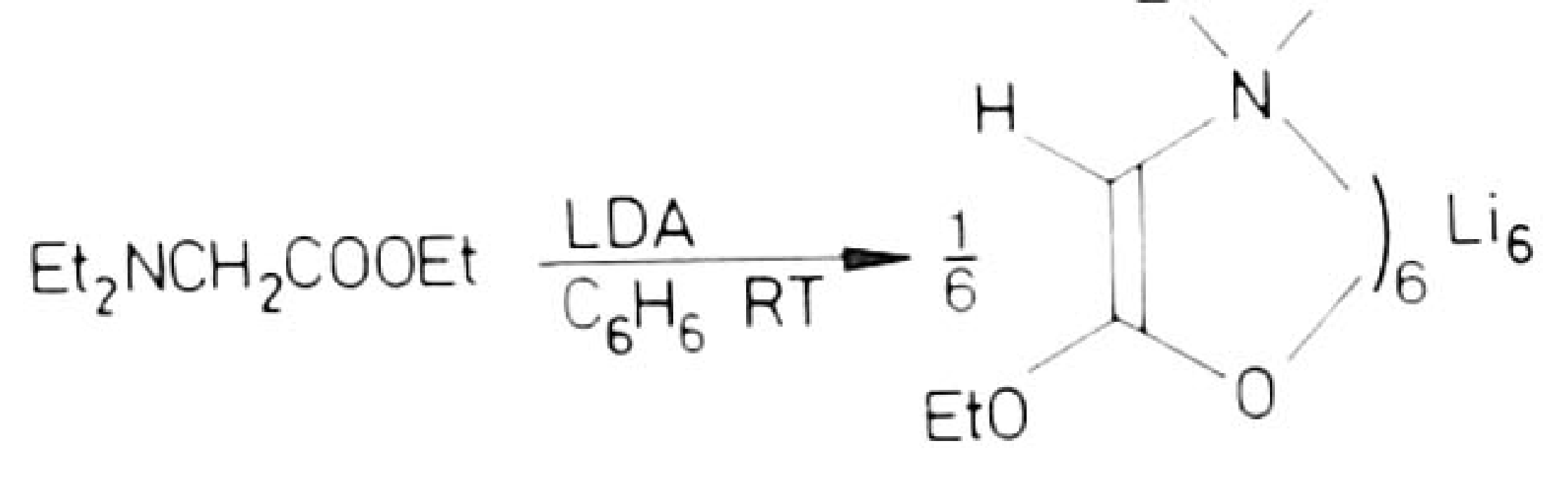

2

\begin{tabular}{|c|c|c|c|c|}
\hline \multirow{2}{*}{\multicolumn{2}{|c|}{1}} & \multicolumn{3}{|c|}{2} \\
\hline & & Lactam & Yield & starting imine \\
\hline $4 a$ & $R=P h$ & $R^{\prime}=M e$ & $95 \%$ & $R^{\prime}=M e$ \\
\hline $4 b$ & $R=P h$ & $\mathrm{R}^{\prime}=\mathrm{CH}_{2} \mathrm{Ph}$ & $98 \%$ & $\mathrm{R}^{\prime}=\mathrm{CH}_{2} P h$ \\
\hline $4 c$ & $R=P h$ & $R^{\prime}=H$ & $93 \%$ & $\mathrm{R}^{\prime}=\mathrm{SiMl}_{3}$ \\
\hline $4 d$ & $R=C \equiv C-P h$ & $R^{\prime}=H$ & $98 \%$ & $R^{\prime}=\operatorname{SiMe}_{3}$ \\
\hline $4 e$ & $R=C \equiv C-\mathrm{SiMe}_{3}$ & $R^{\prime}=H$ & $97 \%$ & $R^{\prime}=\operatorname{SiMe}_{3}$ \\
\hline
\end{tabular}


and $\mathbf{3 b}$; this geometry was established for the lithium enolate 2 by X-ray crystallography. ${ }^{12}$ (Others have found that cis-trans mixtures of $\beta$-lactams result from erythro adducts formed from zinc ester enolates and imines under Reformatsky conditions). 13

To our knowledge the new route described in this paper for the high-yield synthesis of exclusively trans- $\beta$-lactams is without precedent and studies regarding its synthetic scope are being carried out. Structural investigations of the enolates are also in progress. Both the ethylzinc enolate $\mathbf{3 a}$ and the chlorozinc enolate $\mathbf{3 b}$ appear to be formed as aggregates with $\mathrm{LiCl}$ (1.0 and 0.5 equiv. respectively) as depicted in Scheme 1. These species are soluble in benzene and provide complex temperature dependent $250 \mathrm{MHz} .{ }^{1} \mathrm{H}$ NMR spectra which have not yet been fully interpreted. Results of these investigations into both the applications and mechanism of this new synthetic route will be the subject of forthcoming papers.

\section{Acknowledgement}

We are grateful to Gist-Brocades N.V., The Netherlands, for financial support during this research. Thanks are due to Dr. D.M. Grove for critical and stimulating discussions and $\mathrm{Mr}$. H. Kleijn for his experimental assistance.

\section{References and Notes}

1. Chemistry and Biology of $\beta$-Lactam antibiotics, Vol 1-3, R.B. Morin, and M.Gorman, Ed.; Academic Press, New York, London, 1982.

2. For a recent comprehensive review of $\beta$-lactam syntheses, see: G.A. Koppel, In 'Small Ring Heterocycles -Azetidines, $\beta$-Lactams, Diazetidines and Diaziridines'; A.Hassner, Ed., Wiley, New York, Chapter 2 (1982).

3. D.A. Evans, J.V.Nelson, and T.R.Taber, In 'Topics in Stereochemistry', Vol 13, 'Stereoselective Aldol Condensations', N.L.Allinger, E.L.Eliel, and S.H.Wilen, Wiley, New York, 1-115 (1982).

4. M.Gaudemar, Organomet. Chem. Rev. A , 8, 183 (1972).

5. G.Gluchowski, L.Cooper, D.E.Bergbreiter, and M.J.Newcomb, J.Org .Chem.,45, 3413 (1980).

6. D.J. Hart, K. Kanai, D.G. Thomas, and T-K. Yang, J. Org. Chem., 48, 289 (1983).

7. L.E. Overman, and T.J. Osawa, J. Amer .Chem. Soc., 107, 1698 (1985).

8 a. M.R.P. van Vliet, J.T.B.H. Jastrzebski, W.J. Klaver, K. Goubitz, and G. van Koten, Recl. Trav. Chim. Pays-Bas, 106, 132 (1987). b. These enolates are formed in the reaction of $\mathrm{ZnEt}_{2}$ with, for example, the $\alpha$-iminoketone $\mathrm{t}-\mathrm{BuN}=\mathrm{C}(\mathrm{H}) \mathrm{C}(\mathrm{Me})=\mathrm{O}$ via the formation of the $\sigma-\mathrm{N}, \sigma-\mathrm{O}-\mathrm{ZnEt}_{2}$ iminoketone precursor complex and subsequent migration of an ethyl group from zinc to the imino-N atom, see 8c.c. M.R.P. van Vliet, G. van Koten, P. Buysingh, J.T.B.H. Jastrzebski, and A.L. Spek, Organometallics, 6, 537 (1987).
9. ${ }^{1} \mathrm{H}$ NMR spectra in $\mathrm{CDCl}_{3}$ at $60 \mathrm{MHz}, \delta$ values in ppm relative to internal $\left(\mathrm{CH}_{3}\right)_{4} \mathrm{Si}$. Compound $4 \mathrm{a}$ $:{ }^{1} \mathrm{H}$ NMR : $\delta 1.15\left(\mathrm{t}, 6 \mathrm{H}, \mathrm{NCH}_{2} \mathrm{CH}_{3}\right), 2.90(\mathrm{q}$, $\left.4 \mathrm{H}, \mathrm{NCH}_{2} \mathrm{CH}_{3}\right), 2.90$ (s, 3H, NCH 3 ), 4.10 (d, $1 \mathrm{H}$, $\left.\mathrm{NCHCHPh},{ }^{3} \mathrm{~J}_{\mathrm{H} H} 1.6 \mathrm{~Hz} .{ }^{0}\right), 4.60$ (d, $1 \mathrm{H}$, $\left.\mathrm{NCHC} \underline{\mathrm{HPh}},{ }^{3} \mathrm{~J}_{\mathrm{HH}}{ }^{1.6 \mathrm{~Hz}}{ }^{\mathrm{l}}{ }^{2}\right), 7.30(\mathrm{~m}, 5 \mathrm{H}, \mathrm{Ph})$ Mp. $70-71^{\circ} \mathrm{C} ;$ Analysis found (calcd.) C 72.13 (72.38), $\mathrm{H} 8.80$ (8.68), N 11.73 (12.06).Compound 4b : ${ }^{1} \mathrm{H}$ NMR : $\delta 1.20(t, 6 \mathrm{H}$, $\left.\mathrm{CH}_{2} \mathrm{CH}_{3}\right), 2.90\left(\mathrm{~m}, 4 \mathrm{H}, \mathrm{NCH}_{2} \mathrm{CH}_{3}\right), 3.90$ and 5.10 (d, d, $\left.1 \mathrm{H}, 1 \mathrm{H}, \mathrm{NCH}_{2} \mathrm{Ph},{ }_{\mathrm{J}} \mathrm{H}_{\mathrm{H}} 15 \mathrm{~Hz}.\right), 4.20$ (d, $\left.1 \mathrm{H}, \mathrm{NCHCHPh},{ }^{3} \mathrm{~J}_{\mathrm{HH}} 15 \mathrm{~Hz}{ }^{-}\right), 4.60(\mathrm{~d}, 1 \mathrm{H}$, $\left.\mathrm{NCHC}{ }_{\mathrm{HPh}}{ }^{3} \mathrm{~J}_{\mathrm{HH}} 1.5 \mathrm{~Hz}^{10}\right), 7.40(\mathrm{~m}, 10 \mathrm{H}, \mathrm{Ph})$. Compound $4 \mathrm{c}$ : ${ }^{\mathrm{H}}$ NMR : $\delta 1.20(\mathrm{t}, 6 \mathrm{H}$, $\mathrm{NCH}_{2} \mathrm{CH}_{3}$ ), 2.90 (q, $\left.4 \mathrm{H}, \mathrm{NCH}_{2} \mathrm{CH}_{3}\right), 4.15$ (d, $\left.1 \mathrm{H}, \mathrm{NC} \underline{\mathrm{H} C H P h}, 3_{\mathrm{J}} \mathrm{H} 1.5 \mathrm{~Hz}^{\mathrm{\theta}}\right), 4.80(\mathrm{~d}, 1 \mathrm{H}$, $\left.\mathrm{NCHC} \underline{\mathrm{H}} \mathrm{Ph},{ }^{3} \mathrm{~J}_{\mathrm{H}} 1.5 \mathrm{~Hz}^{10}\right), 6.70(\mathrm{~s}, 1 \mathrm{H}$,

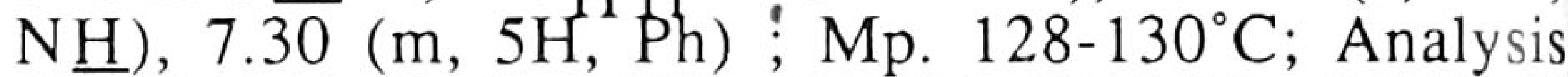
found (calcd) C 71.29 (71.53), ${ }_{1} \mathrm{H} 8.39$ (8.31), N 12.79 (12.83). Compound 4d : ${ }^{\mathrm{H}}$ NMR : $\delta 1.15$ (t, $\left.6 \mathrm{H}, \mathrm{NCH}_{2} \mathrm{CH}_{3}\right), 2.95$ (q, $\left.4 \mathrm{H}, \mathrm{NCH}_{2} \mathrm{CH}_{3}\right), 4.45$ (s, $2 \mathrm{H}, \mathrm{NC} \underline{\mathrm{HC}} \mathrm{HC} \equiv \mathrm{C}$ and $\mathrm{NCHC} \underline{\mathrm{HC}} \equiv \mathrm{C}), 6.10$ (s, $1 \mathrm{H}, \mathrm{NH}), 7.30$ (s, $5 \mathrm{H}, \mathrm{Ph}) ; \mathrm{Mp} .116-117{ }^{\circ} \mathrm{C}$; Analysis found (calcd) C 74.29 (74.35), $\mathrm{H}$ 7.56 (7.49), N 11.57 (11.56). Compound $4 \mathrm{e}:{ }^{1} \mathrm{H}$ NMR : $\delta \quad 0.30\left(\mathrm{~s}, 9 \mathrm{H}, \mathrm{Si}\left(\mathrm{C}_{3}\right)_{3}\right), 1.15(\mathrm{t}, 6 \mathrm{H}$, $\left.\mathrm{NCH}_{2} \mathrm{CH}_{3}\right), 2.80\left(\mathrm{q}, 4 \mathrm{H}, \mathrm{NCH}_{2} \mathrm{CH}_{3}\right), 4.25$ (d, $\left.1 \mathrm{H}, \mathrm{NCHCHC}_{\overline{3}} \mathrm{C},{ }^{3} \mathrm{~J}_{\mathrm{HH}} 1.5 \mathrm{~Hz} .{ }^{2}\right), 4.40(\mathrm{~d}, 1 \mathrm{H}$, $\left.\mathrm{NCHC} \underline{\mathrm{HC}} \equiv \mathrm{C},{ }^{3} \mathrm{~J}_{\mathrm{HH}}{ }^{1.5} \mathrm{~Hz} .{ }^{10}\right), 6.55(\mathrm{~s}, 1 \mathrm{H}, \mathrm{N} \underline{\mathrm{H}})$ Mp. $108-109^{\circ} \mathrm{C}$; Analysis found (calcd) C 60.07 (60.46), H 9.16 (9.30), N 11.67 (11.75).

10. A value of about $2 \mathrm{~Hz}$ for ${ }^{3} \mathrm{~J}_{\mathrm{HH}}$ is typical for trans- $\beta$-lactams, for cis- $\beta$-lactams this value is about $6 \mathrm{~Hz} .:$ H.B. Luche, H.B. Kagan, R. Parthasarathy, $G$. Tsoucaris, $C$. de Rango, and $C$. Zelwer, Tetrahedron, 24, 1275 (1968).

11. ${ }^{\mathrm{H}}$ NMR spectroscopy of a $\mathrm{CDCl}_{3}$ solution of racemic $4 \mathrm{a}$ shows a resonance at $4.60 \mathrm{ppm}$ assigned to the hydrogen atom at the 4-position. On addition of tris[3-trifluoromethylhydroxy - methylene)-d-camphorato]europium(III) one obtains instead two resonances in a $1: 1$ intensity ratio (separated by about $0.3 \mathrm{ppm}$ ) due to the presence of equivalent amounts of the two enantiomers. For the product obtained from the reaction of the enantiomerically pure (-)menthyl ester the intensity ratio of these resonances was $2: 1$.

12. J.T.B.H. Jastrzebski, W.F. van de Mieroop, and $G$. van Koten, J. Organometal. Chem., submitted.

13. Although it has been previously shown that reaction of several zinc ester enolates 4 a with $\mathrm{N}$-phenylbenzaldimine ${ }^{14 \mathrm{~b}}$ at temperatures from -10 to $-18^{\circ} \mathrm{C}$ affords exclusively erythro adducts, $14 \mathrm{c}, \mathrm{e}$ upon warming cis-trans mixtures of $\beta$-lactams are obtained from these aldolates. In these cases it was shown that the loss in stereochemistry was due to retroaldolization. In the present study it is most probably the exclusive Z-enolate formation that is crucial for the observed stereoselectivity.

14. a The stereochemistry of these enolates was not established,but for steric reasons these are most likely to have been E. b. The preferred geometry for aldimines is E. c. J.L. Luche, and H.B. Kagan, Bull. Soc. Chim. Fr., 2260 (1971). d. F. Dardoize, J.L. Moreau, and M.C. Gaudemar, R. Acad. Sci., Ser. C, 270, 233 (1970). e. F. Dardoize, J.L. Moreau, and M. Gaudemar, Bull. Soc. Chim. Fr., 1668 (1973)

15. D.A. Burnett, D.J. Hart and J. Liu, J. Org. Chem., 51, 1929 (1986).

16. D.J. Hart, K. Kanai, D.G. Thomas and T.K. Yang, J. Org. Chem., 48, 289 (1983). 